\title{
FATORES GEOLÓGICOS PARA PLANEJAMENTO DE USO E OCUPAÇÃO TERRITORIAL - EXEMPLO DE SANTOS -
}

U.Duarte ${ }^{1}$

\section{INTRODUÇÃO}

O crescimento desenfreado da urbanização, com o uso e ocupação pouco criteriosos do solo, tem acarretado problemas consideravelmente graves, senão catastróficos. Assim, locais extremamente problemáticos do ponto de vista do meio físico, são parcelados e ocupados mais sob a influência de razões de mercado do que reais potencialidades das áreas a serem ocupadas.

Este resumo visa dar conhecimento do estudo que está sendo realizado no Município de Santos - continente -, onde foram levadas em consideração: características geomorfológicas (formas de relevo, declividade das encostas, processos de evolução do relevo), geológicas (tipos litológicos, formas de ocorrências, estruturas), geotécnicas (propriedades dos solos e rochas) recursos hídricos (superficiais e subterrâneos) e recursos minerais (pedra britada e areia) do meio físico.

\section{ÁREA DE ESTUDO}

A região estudada é aquela compreendida na porção continental do Município de Santos, que possui uma extensão territorial de $752 \mathrm{~km}^{2}$. A ocupação urbana do município se deu principalmente na porção insular, que representa somente cerca de $10 \%$ do seu território, provocando hoje uma saturação do espaço urbano, e conseqüente uso indevido

\footnotetext{
${ }^{1}$ Departamento de Geologia Econômica e Geofísica Aplicada, Instituto de Geociências/USP, São Paulo.
} 
de terrenos marginais e encostas.

\section{CARACTERÍSTICAS FÍSICAS ESTUDADAS}

\section{1 - Geologia}

Foram compilados e analisados os estudos geológicos referentes à região estudada, com posterior aferimento do campo, e daí elaborado um mapa geológico em escala 1:50.000 para a área de interesse.

\section{2 - Geomorfologia}

Elaborou-se uma carta geomorfológica da região envolvendo estudo das variáveis do meio físico relacionados aos processos de evolução das encostas e análise da dinâmica dos processos erosivos e deposicionais, na mesma escala do mapa geológico.

\section{3 - Declividade}

A elaboração da carta de declividade baseou-se na leitura das curvas de nível através do deslocamento sobre a base topográfica de ábaco construído com espaçamento representativo dos intervalos correspondentes às classes de declividade escolhidas, de modo a atender às finalidades do estudo.

\section{4 - Risco Geológico}

A carta de risco geológico foi executada a partir de interpretação das carta geológica, geomorfológica e de declividade, onde foram admitidas três possiblidades de análise quanto às classes de risco a serem adotadas, como procedimento para qualificação dos terrenos, com menor ou maior grau de risco para seu uso e ocupação.

\section{5 - Recursos Hídricos}

Tendo em vista necessidade primordial da água, para qualquer tipo de uso e ocupação do solo, principalmente quando relacionada a áreas para urbanização, foram estudados e quantificados os recursos hídricos disponíveis na região (superficiais e subterrâneos), em termos de qualidade e quantidade. 


\section{6 - Recursos Minerais}

Outra necessidade para o desenvolvimento racional de um planejamento de uso e ocupação é aquele relacionado à existência de recursos minerais, principalmente os relacionados a matérias primas para construção civil. Assim foram quantificadas as principais explorações da região, e estimada sua potencialidade para uso futuro.

\section{7 - Carta de uso e ocupação}

Esta carta, de maior importância para os responsáveis por planejamento de uso e ocupação do solo, está sendo elaborada levando-se em consideração principalmente a carta de riscos geológicos e a potencialidade dos recursos hídricos e minerais, respeitando-se a vocação ocupacional da região, parques estaduais, zonas de preservação, locais de tombamento histórico e paisagístico e leis municipais, estaduais e federais.

\section{CONCLUSÕES}

Ao final deste estudo pretende-se demostrar que somente as cartas geotécnicas para finalidades de uso e ocupação territorial são insuficientes aos setores de planejamento, havendo necessidade de estudo dos recursos hídricos e minerais, os quais podem ou não inviabilizar os projetos a serem implantados. 